\title{
Peningkatan Kesiapsiagaan Siswa Sekolah Dasar dalam Menghadapi Bahaya Gempa Bumi dan Tsunami
}

\author{
Aris Munandar ${ }^{1 *}$, Suhardjo ${ }^{1}$, Dwi Sukanti Lestariningsih ${ }^{1}$, dan Ode Sofyan Hardi ${ }^{1}$ \\ ${ }^{1}$ Jurusan Geografi Fakultas Ilmu Sosial Universitas Negeri Jakarta, Jakarta, Indonesia \\ *Email korespondensi: arisbrebes77@gmail.com
}

\begin{abstract}
Abstrak
Tujuan kegiatan ini 1). Memberikan pemahaman yang benar tentang jenis-jenis bencana, tempat penyelamatan diri ketika terjadi bencana. 2) Melakukan simulasi penyelamatan diri ketika terjadi bencana. Sasaran dalam kegiatan ini adalah siswa di 3 sekolah yang memiliki resiko tinggi yaitu SD 1,2 dan 3 Sawarna Kecamatan Bayah Kab. Lebak Banten. Jumlah peserta 35 siswa terdiri dari 20 siswi dan 15 siswa. Metode pelaksanaan dibagi menjadi 3, yaitu penyampaian materi, permainan, dan simulasi. Penyampaian materi meliputi: penayangan video, memberikan kuis. Penayangan video berisi pengenalan jenis bencana yang ada yaitu: gempa bumi, tsunami, tanah longsor, banjir, angin puting beliung/topan, kebakaran, gunung meletus. Materi berikutnya tayangan berupa lokasi-lokasi yang aman ketika bencana tersebut terjadi. Video menggambarkan lokasi mana yang harus dituju dan dihindari. Setelah ditayangkan video kemudian dilakukan evaluasi sejauh mana pemahaman tentang bencana lingkungan yang mengancam. Permainan dilakukan dengan mengklasifikasikan jenis bencana. Kegiatan terakhir yaitu simulasi ketika terjadi gempa dengan menggunakan nyanyian dan peragaan.vSecara umum dari hasil evaluasi dan hasil simulasi dapat berjalan sesuai dengan tujuan. Peserta dapat memahami jenis bencana, bencana yang mungkin terjadi dilingkungannya, dapat memahami tempat yang dituju ketika terjadi gempa maupun tsunami. Peserta dapat mengikuti simulasi dengan sambil bernyanyi. Harapannya setelah mendapatkan pemahaman yang benar dapat ditularkan kepada teman-temannya yang lain, maupun keluarga dan masyarakat pada umumnya. Perlu adanya sosialisasi yang lebih luas kepada siswa-siswa yang lain mengingat bahaya tsunami yang mengancam di tiga sekolah. Sosialiasai berupa penempelan poster/gambar tentang jenis bahaya dan usaha untuk mnyelematkan diri jika terjadi bencana.
\end{abstract}

Kata Kunci: Kesiapsiagaan, Siswa, Gempa Bumi, Tsunami

\begin{abstract}
The purpose of this activity is 1). Provide a correct understanding of the types of disasters, places to save themselves when a disaster occurs. 2) Perform a self-rescue simulation when a disaster occurs. The objectives in this activity are students in 3 schools that have high risk namely SD 1, 2 and 3 Sawarna Bayah District. Lebak Banten The number of participants was 35 students consisting of 20 female students and 15 male students. The implementation activity is divided into 3, namely the transfer knowledge, games, and simulations. Submission of material includes: video screening, giving quizzes. Video shows contain an introduction to the types of disasters, namely: earthquakes, tsunamis, landslides, floods, hurricanes / typhoons, fires, volcanic eruptions. The next material is in the form of safe locations when the disaster occurs. Video describes which locations should be addressed and avoided. After the video was aired, an evaluation of the extent of understanding of threatening environmental disasters was carried out. The game is done by classifying types of disasters. The last activity is a simulation when an earthquake occurs using singing. In general, the results of evaluation and simulation results can run according to the objectives. Participants can understand the types of disasters, disasters that may occur in their environment, can understand the destination when an earthquake or tsunami occurs. Participants can take part in the simulation while singing. The hope after getting the right understanding can be transmitted to other friends, as well as family and society in general. There needs to be broader socialization to other students given the threat of tsunami threatening in three schools. Socialization is in the form of posting posters / images about the types of hazards and efforts to save themselves in the event of a disaster.
\end{abstract}

Keywords: Preparedness, Students, Hazard, Earthquake, Tsunami. 
Format Sitasi: Munandar, A., Suhardjo, S., Lestariningsih, D.S., Hardi, O.S. (2019). Peningkatan Kesiapsiagaan Siswa Sekolah Dasar dalam Menghadapi Bahaya Gempa Bumi dan Tsunami. Jurnal Solma, 8(2), 210-218. Doi: https://dx.doi.org/10.29405/solma.v8i2.2892

Diterima: 09 Januari 2019 | Revisi: 29 Juni 2019 | Dipublikasikan: 21 Oktober 2019

(C) 2019. Oleh authors. Lisensi Jurnal Solma, LPPM-Uhamka, Jakarta. Artikel ini bersifat open access yang didistribusikan di bawah syarat dan ketentuan Creative Commons Attribution (CC-BY) license. (http://creativecommons.org/licenses/by/4.0/).

\section{PENDAHULUAN}

Bahwa kondisi alam di Indonesia menyebabkan timbulnya risiko terjadinya bencana alam, bencana ulah manusia dan kedaruratan kompleks, meskipun disisi lain juga kaya akan sumberdaya alam. Pada umumnya Indonesia memiliki ancaman bencana alam meliputi bencana akibat faktor geologi (gempabumi, tsunami dan letusan gunung api), bencana akibat hidrometeorologi (banjir, tanah longsor, kekeringan, angin topan), bencana akibat faktor biologi (wabah penyakit manusia, penyakit tanaman/ternak, hama tanaman) serta kegagalan teknologi (kecelakaan industri, kecelakaan transportasi, radiasi nuklir, pencemaran bahan kimia) (BNPB, 2017). Bencana akibat ulah manusia terkait dengan konflik antar manusia akibat perebutan sumberdaya yang terbatas, alasan ideologi, religius serta politik. Sedangkan kedaruratan kompleks merupakan kombinasi dari situasi bencana pada suatu daerah.

Bencana alam dapat terjadi secara tiba-tiba maupun melalui proses yang berlangsung secara perlahan (Widianto, 2011). Beberapa jenis bencana seperti gempa bumi, hampir tidak mungkin diperkirakan secara akurat kapan, dimana akan terjadi dan besaran kekuatannya. Sedangkan beberapa bencana lainnya seperti banjir, tanah longsor, kekeringan, letusan gunungapi, tsunami dan anomali cuaca masih dapat diramalkan sebelumnya. Meskipun demikian kejadian bencana selalu memberikan dampak kejutan dan menimbulkan banyak kerugian baik jiwa maupun materi. Kejutan tersebut terjadi karena kurangnya kewaspadaan dan kesiapan dalam menghadapi ancaman bahaya. Kesiapsiagaan adalah serangkaian kegiatan yang dilakukan sebagai upaya untuk menghilangkan dan/atau mengurangi ancaman bencana (BNPB, 2012).

Berdasarkan data laporan BPBD Lebak terjadi gempa bumi yang terjadi diwilayahlaut barat daya Kabupaten Lebak selas 23 Januari 2018. Pukul 13.35 WIB. Gempa dengan kekuatan 6,1 skala Richter. Kerusakan dilaporkan di 7 Kecamatan yaitu Kec. 
Sobang, Panggarangan, Wanasalam, Bayah, Cilongrang, Lebak Gedong dan Cimarga. Terdapat 180 rumah di Desa Sawarna yang mengalami rusak berat dan ringan akibat terjadinya gempa.

Salah satu di desa di Kabupaten Lebak adalah Desa Sawarna Kecamatan Bayah. Desa Sawarna memiliki potensi bencana gempa bumi dan tsunami. Perlu adanya pengetahuan tentang bencana yang mengancam dilingkungannya. Penyadaran pengetahuan pemahaman ancaman bencana lingkungan dapat melalui sekolah.

Pada tahun 2006, hasil penelitian dari Lembaga Ilmu Pengetahuan Indonesia (LIPI) bekerjasama dengan United Nations Educational, Scientific and Cultural Organization (UNESCO) di tiga daerah di Indonesia (Aceh, Bengkulu, dan Padang) menyatakan bahwa kesiapsiagaan bencana untuk sekolah adalah paling rendah dibandingkan dengan kesiapsiagaan rumah tinggal dan masyarakat (LIPI, 2007). Pengenalan bahaya yang mengancam lingkungan pada siswa menjadi penting karena dapat menyebarkan informasi kepada lingkungan disekolah sendiri, menyebar kerumah dan lingkungan masyarakat. Melalui pemasangan poster-poster yang dapat dipahami menjadi media yang menarik untuk dilihat, sehingga siswa tertarik untuk memahaminya (Tim Pengembang, 2008). Sosialisasi dengan media ini dapat memberikan pengetahuan kepada siswa tentang jenis bahaya yang kemungkinan terjadi.

Sekolah merupakan salah satu media yang efektif dalam menerapkan kesiapsiagaan bencana. Sekolah mempunyai potensi yang sangat besar sebagai sumber pengetahuan, penyebar-luasan pengetahuan tentang bencana dan petunjuk praktis apa yang harus disiapkan sebelum terjadinya bencana apa yang harus dilakukan pada saat dan setelah terjadinya bencana (Sopaheluwakan \& Deni, 2006). Berbagai program dan terminologi yang pernah dikembangkan adalah Sekolah Siaga Bencana (SSB), Pengurangan Risiko Bencana Berbasiskan Sekolah (PRBBS), dan Sekolah Ramah Anak (SRA) (Institut Pertanian Bogor, 2011). Kurangnya pengetahuan tentang kesiapsiagaan bencana menyebabkan banyaknya korban. Sosialisasi dengan mengadakan simulasi penyelamatan diri jika bahaya itu muncul/terjadi. Siswa lebih waspada dan tidak panik karena sudah memiliki softskill dalam usaha penyelematan diri. Jika bencana terjadi minimal dapat mengurangi korban, karena siswa sudah memiliki bekal pengetahuan, sikap dan ketrampilan yang cukup (BNPB, 2017).

\section{MASALAH}

Ketidaktahuan bahaya yang mengancaman menyebabkan siswa tidak tahu bagaiman usaha untuk menyelamatkan diri. Memerlukan simulasi untuk menyelamatkan diri jika 
bencana itu terjadi maka perlu dilakukan usaha untuk meningkatkan kesiapan siswa-siswa SD di Sawarna dalam menghadapi bahaya yang mengancam.

\section{METODE PELAKSANAAN}

Sasaran dalam kegiatan ini siswa SD kelas tinggi yaitu 4,5,6 di 3 sekolah yaitu SD 1,2,3 Sawarna. Metode pelaksanaan kegiatan ada tiga yaitu transfer pengetahuan, permainan, simulasi. Transfer pengetahuan dilakukan dengan cara penayangan video, permainan dengan mengelompokan jenis bencana menjadi dua. Mengadakan simulasi dengan menggunakan nyanyian dan peragaan (Bengen, 1999). Pelaksanaan program diketahui dengan cara evaluasi tertulis kepada peserta, dimana diajukan empat pertanyaan yang berkaitan dengan jenis bencana, lokasi untuk menyelamatkan diri ketika terjadi bencana gempa dan tsunami. Hasil evaluasi dibuat dalam bentuk grafik untuk melihat kecenderungan jawaban. Soal dalam bentuk esai untuk mengetahui pemahaman secara menyeluruh.

\section{PEMBAHASAN}

Kegiatan dilaksanakan Ruang kelas SD Sawarna 1 Kecamatan Bayah Kab. Lebak. Jumlah peserta 35 siswa terdiri dari 20 siswi dan 15 siswa. Peserta dari 3 sekolah yaitu SD 1 Sawarna (16 orang), SD 2 Sawarna (10 orang) dan SD 3 Sawarna (9 orang). Jarak lokasi kegiatan di SD 1 Sawarna merupakan daerah yang sangat dekat dengan pantai sehingga ketika terjadi tsunami akan berdampak langsung (zona merah). Dua SD lainnya berdekatan dengan lokasi SD sasaran tujuan kegiatan yaitu SD 2 dan SD 3 Sawarna.

Kegiatan pelaksanaan dibagi menjadi 3 sesi, yaitu transfer pengetahuan, permainan dan simulasi. Penyampaian materi meliputi: penayangan video, memberikan kuis. Penayangan video berisi pengenalan jenis bencana yang ada yaitu: gempa bumi, tsunami, tanah longsor, banjir, angin putting beliung/topan, kebakaran, gunung meletus. Pengenalan jenis bencana penting agar siswa mendapatkan pemahaman yang benar tentang jenis bencana yang ada. Materi berikutnya tayangan berupa lokasi-lokasi yang aman ketika bencana tersebut terjadi. Video menggambarkan lokasi mana yang harus dituju dan dihindari ketika bencana itu terjadi. Perbedaan jenis bencana akan membedakan lokasi yang aman untuk menyelematkan diri. Lokasi aman/berbahaya bisa berupa lapangan, rumah, gedung, pantai, dataran tinggi, pohon, sungai. Misalnya jika terjadi bencana gempa lokasi penyelematan diri ke lapangan, lokasi yang dihindari rumah/gedung/pohon. Bencana tsunami lokasi yang 
dituju untuk penyelamatan diri ke gedung tinggi/dataran tinggi, lokasi yang dihindari pantai, sungai dan sebagainya

Setelah ditayangkan video kemudian dilakukan evaluasi sejauh mana pemahaman tentang bencana lingkungan yang mengancam. Jenis pertanyaan dalam bentuk esai sebanyak 4 yaitu: jenis bencana yang diketahui, jenis bencana yang mungkin terjadi dilingkungnnya, tempat penyelamatan diri ketika terjadi tsunami dan tempat penyelamatan diri ketika terjadi gempa.

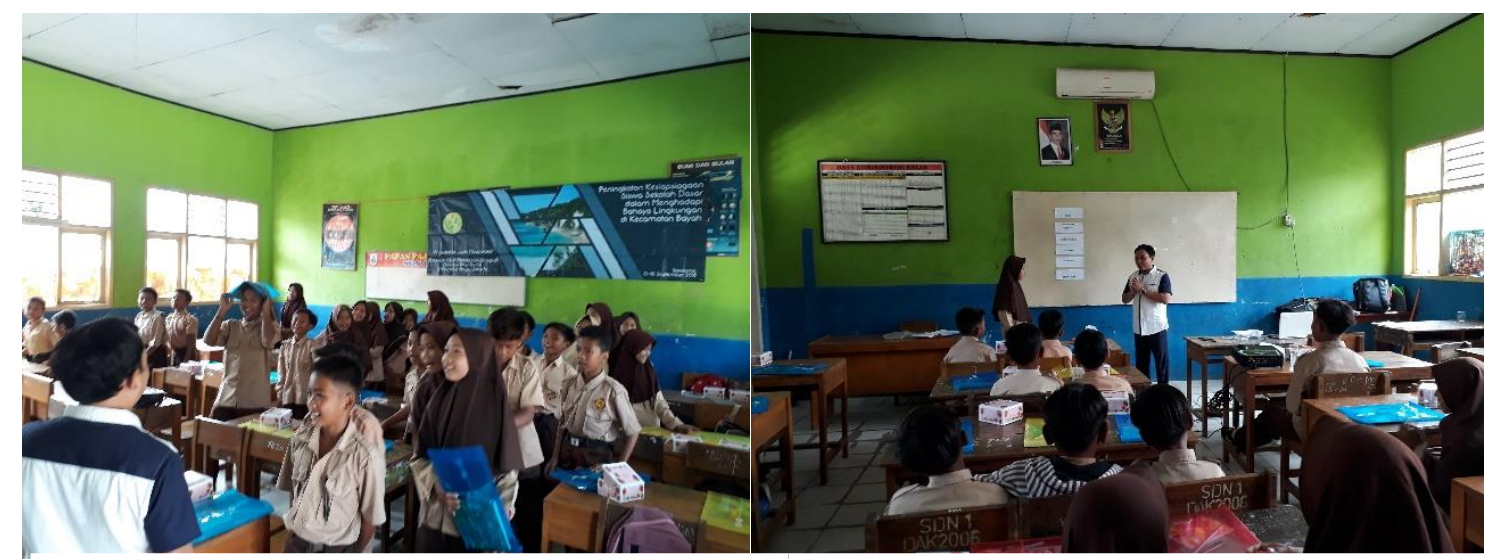

Gambar 1. Kegiatan simulasi Gambar 2. Permainan kartu untuk penyelamatan diri dengan cara berbaris mengklasifikasikan jenis-jenis bahaya menuiu keluar

Kegiatan berikutnya yaitu permainan untuk mengklasifikasikan jenis bencana, yaitu bencana dari alam dan manusia. Peserta diberikan kartu yang berisi jenis bencana. Kemudian kartu ditempelkan di papan tulis dengan dua klasifikasi. Secara umum peserta sudah memahami penggolongan bencana alam (gunung meletus, tsunami, gempa bumi, angin topan) dan campur tangan manusia (banjir, kebakaran, longsor). Peserta memahami penggolongan dibuktikan dengan klasifikan yang diberikan sesuai dengan jawaban dari peserta.

Secara umum dari hasil evaluasi dan hasil simulasi dapat berjalan sesuai dengan tujuan. Peserta yang merupakan siswa sekolah dasar dari 3 sekolah dapat memahami jenis bencana, bencana yang mungkin terjadi dilingkungannya, dapat memahami tempat yang dituju ketika terjadi gempa maupun tsunami. Peserta dapat mengikuti simulasi dengan sambil bernyanyi. Harapannya setelah mendapatkan pemahaman yang benar dapat ditularkan kepada teman-temannya yang lain, maupun keluarga dan masyarakat pada umumnya. Sehingga ketika terjadi bencana jumlah korban dapat diminimalisir. Berikut grafik hasil evaluasi kegiatan: 


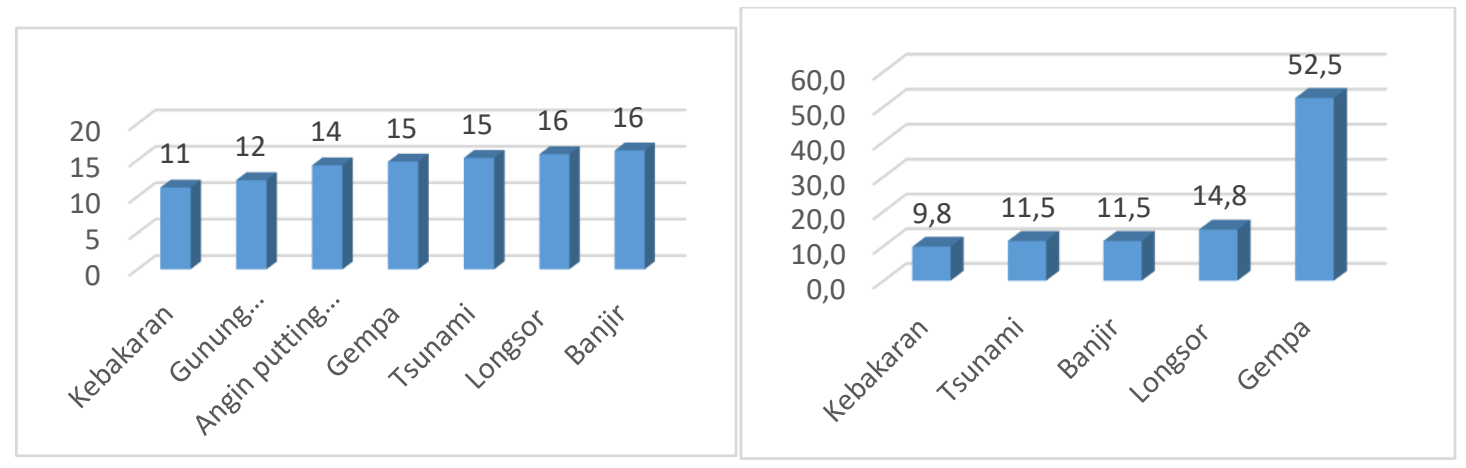

Gambar 3. Jenis bahaya yang diketahui

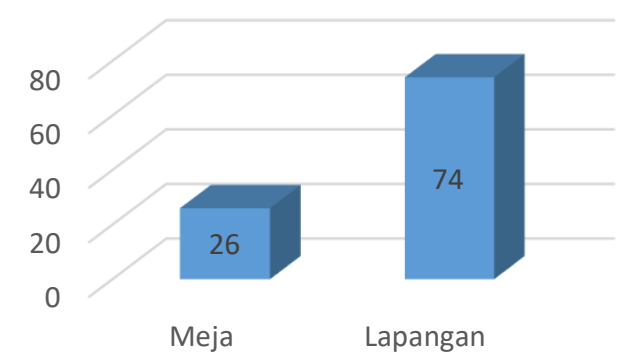

Gambar 5. Tempat menyelamatkan diri jika terjadi gempa
Gambar 4. Jenis bahaya yang ada disekitar

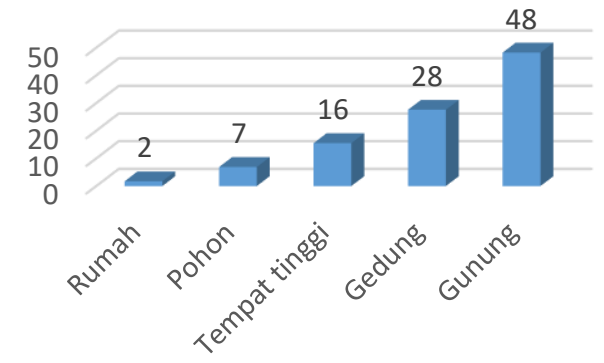

Gambar 6. Tempat menyelamatkan diri jika terjadi stunami

Peserta memahami jenis bencana (Gambar 3), dengan jawaban yang paling banyak bencana banjir dan longsor (16\%) dan yang paling sedikit bencana kebakaran (11\%). Harapannya peserta menjawab semua jenis bencana, yang diketahui, tetapi tidak semua peserta menjawab 7 jenis bencana berdasarkan tayangan video maupun pemehaman peserta.

Berdasarkan jenis bencana yang terjadi dilingkungan sekitarnya (gambar 4), jawaban paling banyak gempa bumi $(52,5 \%)$ dan yang paling sedikit kebakaran $(9,8 \%)$. Peserta memiliki pemahaman yang cukup terhadap bencana yang mungkin terjadi. Peserta tidak ada yang menjawab puting beliung dan gunung meletus. Bencana ini tidak pernah dirasakan atau terjadi pada daerah kajian. Jenis bahaya yang dianggap mungkin terjadi yaitu gempa. Kejadian gempa beberapa kali yang berpusat dipesisir pantai selatan, menjadi kejadian bencana ini sering dan mungkin akan terjadi. Hanya beberapa peserta menjawab jenis bencana tsunami, mungkin terjadi dikarenakan dari kejadian beberapa kali gempa tidak menimbulkan tsunami, sehingga beranggapan tidak mungkin akan terjadi. Pemahaman ini mestinya perlu diluruskan kembali, sehingga peserta lebih waspada terhadap tsunami.

Berdasarkan pertanyaan tempat penyelamatan diri jika terjadi gempa (gambar 5) jawaban yang paling banyak ke lapangan terbuka (74\%), sesuai dengan tayangan yang ada divedio, jawaban ke dua ke kolong meja (26\%). Peserta memahami tempat untuk 
penyelamatan diri ketika terjadi gempa. Lapangan terbuka sebagai tempat untuk menghindar dari runtuhan bangunan yang mungkin membahayakan. Selain kelapangan peserta juga menjawab ke kolong meja untuk menyelamatkan diri. Kolong meja sebagai tempat berlindung ketika peserta dalam kelas/ruangan yang dapat melindungi diri dari runtuhan benda/bangunan (Direktorat Sumber Daya Mineral, 2011). Hasil dari video tayangan memiliki keberhasilan dalam menunjukan tempat yang sesuai untuk menyelamatkan diri.

Berdasarkan pertanyaan tempat penyelamatan diri jika terjadi tsunami (Gambar 7), jawaban yang paling banyak ke gunung sebagai jawaban yang paling banyak (48\%), sesuai dengan tayangan dalam video, jawaban yang lainnya ke gedung, tempat tinggi, pohon dan rumah. Peserta secara umum mengetahaui tempat-tempat yang dituju untuk menyelematkan diri ketika terjadi tsunami. Bencana tsunami yang menjadi ancaman di daerah kajian menjadi ancaman yang cukup membahayakan bagi peserta maupun masyarakat umumnya yang bertempat tinggal di pesisir yang merupakan zona merah/berbahaya (Husein, 1995). Meskipun ada peserta yang menjawab ke rumah, yang tentunya akan membahayakan. Peserta secara umum memahami lokasi untuk menyelematkan diri. Pemahaman bencana tsunami yang kurang mengancam dari jawaban sebelumnya, tetapi peserta memahami jika terjadi bencana tersebut akan melarikan ketempat yang lebih tinggi dapat berupa gunung, gedung, pohon.

Ada lima parameter yang digunakan dalam mengkaji kesiapsiagaan masyarakat dalam menghadap bencana yaitu: pengetahuan dan sikap tentang resiko bencana, kebijakan dan panduan, rencana tanggap darurat, sistem peringatan bencana dan mobilisasi sumber daya (Hidayati, Widayatun, Puji, Triyono, \& Kusumawati, 2017). Kegiatan pengabdian ini merupakan salah satu usaha dalam meningkatkan pengetahuan dan resiko bencana. Peserta yang memiliki pemahaman dan sikap yang benar tentang resiko bencana di daerahnya, dapat meningkatkan kesiapsiaagaan aspek pengetahuan dan sikap.

Peningkatan kapasitas dengan kegiatan sosialisi dan simulasi bagi peserta sangat penting. Ditinjau dari sisi konsep pengurangan risiko bencana, ancaman bencana tersebut dapat mengakibatkan bencana yang besar di wilayah, manakala tingkat kerentanannya (vurnerability) tinggi dan/atau kapasitasnya (capacity) rendah (Sarwidi, Wantoro, \& Suharjo, 2013). Meningkatkan kapasitas peserta dengan kegiatan ini dapat mengurangi resiko bencana gempa bumi dan tsunami yang mungkin terjadi.

\section{KESIMPULAN}

Email: solma@uhamka.ac.id | 216 
Evaluasi dan simulasi dapat berjalan sesuai dengan tujuan. Peserta yang merupakan siswa sekolah dasar dari tiga sekolah dapat memahami jenis bencana, bencana yang mungkin terjadi dilingkungannya, dapat memahami tempat yang dituju ketika terjadi gempa maupun tsunami. Implikasi dari hasil pengabdian ini, peserta dapat melakukan penyelamatan diri ke tempat yang aman jika bencana gempa dan tsunami terjadi. eningkatnya pengetahuan dan sikap meupakan salah satu unsur dari kesiapsiaagaan masyarakat dalam resiko bencana yang mungkin terjadi. Perlu adanya sosialisasi yeng lebih luas kepada siswa-siswa yang lain mengingat bahaya tsunami yang mengancam di tiga sekolah. Sosialiasai berupa penempelan poster/gambar tentang jenis bahaya tsunami dan usaha untuk menyelamatkan diri jika terjadi bencana. Pemasangan poster dapat ditempel di tempat-tempat yang mudah dibaca bagi masyarakat sekitar, seperti di kelas-kelas, papan informasi, pos kamling, pinggir jalan, tempat ibadah (mushola/masjid), aula/ruang pertemuan.

\section{UCAPAN TERIMA KASIH}

Ucapan terima kasih terutama ditujukan kepada Tim pengabdian, FIS UNJ dan Kepala sekolah guru SD 1 Sawarna yang sudah bersedia menjadi lokasi kegiatan. Bencana tidak dapat dihindari, yang dapat dilakukan mengurangi korban dan dampaknya.

\section{DAFTAR PUSTAKA}

Bengen, D. G. (1999). Teknik Pengambilan Contoh dan Analisa Data Biofisik Berwawasan Lingkungan. Direktorat Jenderal Pendidikan Tinggi, Departemen Pendidikan Nasional.

BNPB. Peraturan Kepala BNPB. , Pub. L. No. No 2 Tahun 2012 (2012).

BNPB. (2017a). Definisi dan Jenis Bencana.

BNPB. (2017b). Tanggap Tangkas Tangguh Menghadapi Bencana.

Direktorat Sumber Daya Mineral, D. (2011). Mitigasi Gempa Bumi dan PB. PGRI Yayasan Sampai Gempa Bumi dan Tsunami.

Hidayati, D., Widayatun, Puji, H., Triyono, \& Kusumawati, T. (2017). Panduan Mengukur Tingkat Kesiapsiagaan Masyarakat dan Komunitas Sekolah.

Husein, H. M. (1995). Lingkungan Hidup, Masalah, Pengelolaan dan Sumberdaya Pesisir. Pusat Kajian Sumberdaya Pesisir dan Lautan.

Institut Pertanian Bogor, I. (2011). Konsorsium Pendidikan Bencana. Kerangka Kerja Sekolah Siaga Bencana.

LIPI. (2007). Study of community crisis preparedness 2006-2007 (in Bahasa). Jakarta: 
Indonesian Institute of Science.

Sarwidi, Wantoro, D., \& Suharjo, D. (2013). Evaluasi Sekolah Siaga Bencana (Studi Kasus: SMKN Berbah Kabupaten Sleman, Yogyakarta). Prosiding Seminar Nasional 2013 Menuju Masyarakat Madani Dan Lestari. Yogyakarta: Universitas Islam Indonesia.

Sopaheluwakan, J., \& Deni, H. (2006). Kajian Kesiapsiagaan Masyarakat dalam Mengantisipasi Bencana Gempa Bumi dan Tsunami. Jakarta: Lembaga Ilmu Pengetahuan dan Teknologi.

Tim Pengembang. (2008). Panduan Kurikulum Siaga Bencana SD. PUSKUR.

Widianto, B. 2000. J. L. dan. (n.d.). Lingkungan dan Pembangunan. Jurnal Lingkungan Dan Pembangunan, 20(1). 